TITLE:

\title{
EZH2 inhibitors restore epigenetically silenced CD58 expression in B-cell lymphomas( Abstract_要旨)
}

\author{
AUTHOR(S):
}

Otsuka, Yasuyuki

\section{CITATION:}

Otsuka, Yasuyuki. EZH2 inhibitors restore epigenetically silenced CD58 expression in Bcell lymphomas. 京都大学, 2020, 博士(医学)

ISSUE DATE:

2020-09-23

URL:

https://doi.org/10.14989/doctor.k22727

RIGHT:

https://doi.org/10.1016/j.molimm.2020.01.006 


\begin{tabular}{|c|c|c|c|}
\hline 京都大学 & 博士（医学） & 氏 名 & \\
\hline 論文題目 & \multicolumn{3}{|c|}{$\begin{array}{l}\text { EZH2 inhibitors restore epigenetically silenced CD58 expression in B-cell } \\
\text { lymphomas } \\
\text { (EZH2 阻害薬はB B 細胞リンパ腫においてエピゲノム修飾により抑制された } \\
\text { CD58 発現を回復させる) }\end{array}$} \\
\hline \multicolumn{4}{|c|}{ 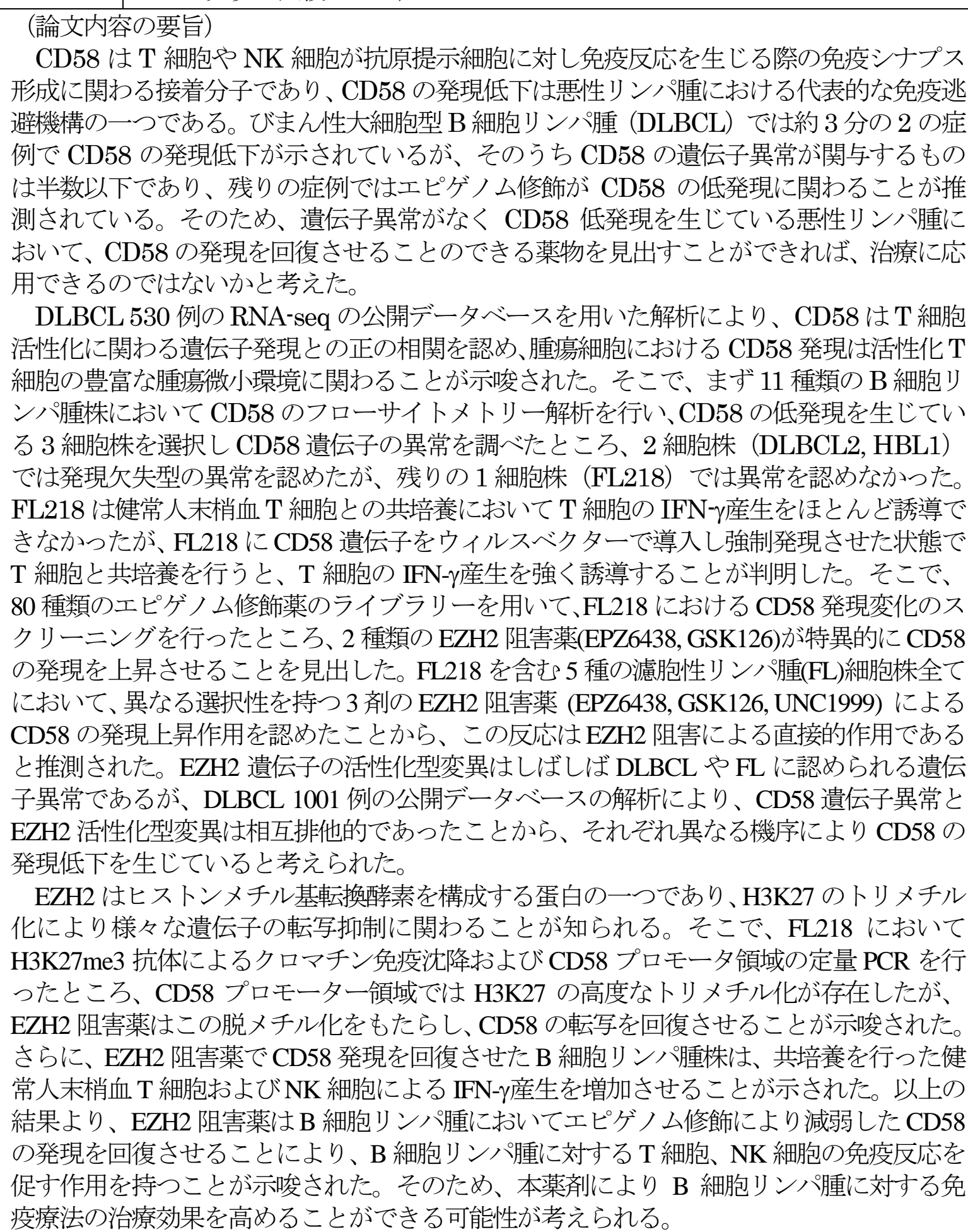 } \\
\hline
\end{tabular}

\section{(論文審査の結果の要旨)}

CD58は、抗原提示細胞、腫瘍細胞に広く発現する接着分子でありCD2のリガンドとして 働く。CD2-CD58結合は、TまたはNK細胞が免疫標的細胞を認識する際に重要である。CD58 の発現低下は悪性リンパ腫における代表的な免疫逃避機構の一つであり、エピゲノム修飾 が関わることが示唆されている。悪性リンパ腫において、CD58の発現を回復させることが できる薬物を探索するため、本研究を行った。

B細胞リンパ腫株のうち、CD58を低発現する濾胞性リンパ腫株FL218にCD58遺伝子をウイ ルスベクターで導入すると、共培養したT細胞を強く活性化することが分かった。そこで 、エピゲノム修飾薬のライブラリーを用いてFL218におけるCD58発現変化のスクリーニン グを行ったところ、EZH2阻害薬がCD58発現を上昇させることを見出した。また、ChiP- ${ }_{\mathrm{qPCR}}$ アッセイでEZH2阻害薬は、FL218においてCD58プロモーター領域のH3K27脱メチル化をもた らすことが示された。さらに、EZH2阻害薬処理後のFL218は共培養T、NK細胞のIFN- $\gamma$ 産生 を増加させ、それはCD2阻害抗体により抑制された。

以上より、EZH2阻害薬はCD58発現回復を通じてB細胞リンパ腫に対するT細胞、NK細胞の 免疫反応を促す作用を持つことが示唆された。

以上の研究はB細胞リンパ腫におけるCD58発現低下とEZH2阻害薬の作用機序の解明に貢 献し、今後の治療開発に寄与寸るところが多い。

したがって、本論文は博士（医学）の学位論文として価值あるものと認める。 なお、本学位授与申請者は、令和 2 年 7 月 31 日実施の論文内容とそれに関連した試問 を受け、合格と認められたものである。

要旨公開可能日： 1 年 $\quad$ 日 $\quad$ 以降

